\title{
Gastric Hepatoid Adenocarcinoma
}

National Cancer Institute

\section{Source}

National Cancer Institute. Gastric Hepatoid Adenocarcinoma. NCI Thesaurus. Code C95747.

A rare adenocarcinoma that arises from the gastric mucosa and is characterized by the presence of large polygonal malignant cells with eosinophilic cytoplasm resembling hepatocytes. 